PROSIDING “DAKWAH DI MASA PANDEMI COVID-19” ISBN : 978-623-94777-0-7

\title{
PEMANFAATAN MEDIA DAKWAH YANG EFEKTIF DI TENGAH PANDEMI COVID 19
}

\author{
Aulya Sofiyanti' ${ }^{1}$, Mada Wijaya Kusumah² \\ ${ }^{1}$ Mahasiswa Prodi Komunikasi Penyiaran Islam, STIBA Ar Raayah Sukabumi, Indonesia \\ ${ }^{2}$ Dosen Prodi Komunikasi dan Penyiaran Islam, STIBA Ar Raayah Sukabumi, Indonesia \\ aulyasofiya06@gmail.com \\ madawk@arraayah.ac.id
}

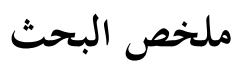

وسائل الدعوة قد تعرف بآلة، أو وسيطة، أو وسيلة، أو كل شيء يمكن استخدامه عند قيام الدعوة لتوصل المعلومات إلى المدعووين. وقد تكون وسائل الدعوة عامدة. للحصول على الهدف الذي قد خطط، ولتوصيل المعلومات إلى المدعوين. والآن، لما انتشر الوباء كوفيد 9 1، إذا استخدمت هذه الوسائل جيدا، فصارت أحسن وآمن وسيلة لتوصيل المعلومات، لأنها قادرة على تبليغ المعلومات إلى أمكنة واسعة في وقت واحد. بناء على هذا، حاولت باحثة على بيان تطوير انتفاع وسائل الدعوة في زمان الوباء كوفيد 91 1، حتى لا يتوقف نشر الفكر الإسلامية. شرح هذا البحث على المنهج المختلط ا الذي يقيد نشاطه على مجموعة المكتبة وبرنامج تحليل وسائل التواصل الإجتماعي. والنتيجة من هذا البحث تدل على : أن وسائل الدعوة لها دور كبير في نجاح الدعوة. وسائل الدعوة لها أعداد كثيرة ومتنوعة. طريقة استفادة وسائل الدعوة في زمان الوباء هي إضافة تكرر البث الإسلمي، وتنوع الموضوعات المجذبة، والتغليف الجديد عند تقديم. 


\begin{abstract}
Abstrak
Penelitian ini berusaha meneliti media dakwah manakah yang dapat digunakan secara efektif untuk berdakwah di masa pandemi Covid 19. Media dakwah merupakan sarana, kanal, alat, atau sesuatu yang dapat digunakan dalam berdakwah. Media dakwah menjadi perantara pesan atau materi dakwah dari komunikator kepada komunikan. Di saat pandemi Covid 19 yang tengah mewabah ini, terdapat beragam media dakwah jika seorang dai menggunakan media dakwah yang tepat maka dapat menjadi media paling efektif dan aman dalam menyampaikan Islam pada masyarakat. Namun bila menggunakan media yang tidak tepat maka penyebaran virus Corona dapat semakin meluas. Penelitian ini menggunakan pendekatan kepustakaan dan studi literatur. Hasil yang diperoleh dari penelitian tersebut yaitu; bahwa televisi, media social, media cetak, dan radio adalah media dakwah yang efektif yang dapay digunakan di masa Pandemi Covid. Dengan pemanfaatan penambahan frekuensi siaran, mengangkat tema-tema menarik, dan memberikan kemasan baru dalam penyajiannya, maka dakwah akan menjadi lebih optimal.
\end{abstract}

Kata kunci : Media Dakwah, Teknologi, Pandemi Covid 19

\title{
I. Pendahuluan
}

Dewasa ini, aktivitas dakwah mengalami evolusi yang massif dalam ruang publik. Hal ini ditunjukkan dengan munculnya keanekaragaman bentuk dakwah. Faktor lain yang menjadi pemicu keberagaman bentuk dakwah adalah media dakwah (Fakhruroji, 2010). Tidak dapat dipungkiri bahwa media dakwah juga memiliki andil yang besar dalam menyebarkan dan mengajarkan agama islam.

Media dakwah merupakan alat yang dijadikan perantara oleh seorang daiyah untuk menerapkan konsep-konsep dakwah baik secara moral maupun material (Al Bayanuni, 1995). Keberhasilan sebuah dakwah juga dapat dipicu dari menarik atau tidaknya sarana dakwah tersebut. Maka tidah aneh jika para penyeru dan pemuka agama terus melakukan pembaruan dan meragamkan sarana dakwah mereka agar pesan yang mereka sampaikan dapat tersalurkan dan diterima dengan baik oleh sasarannya. Allah juga telah menjelaskan dalam firman-Nya, yang berbunyi :

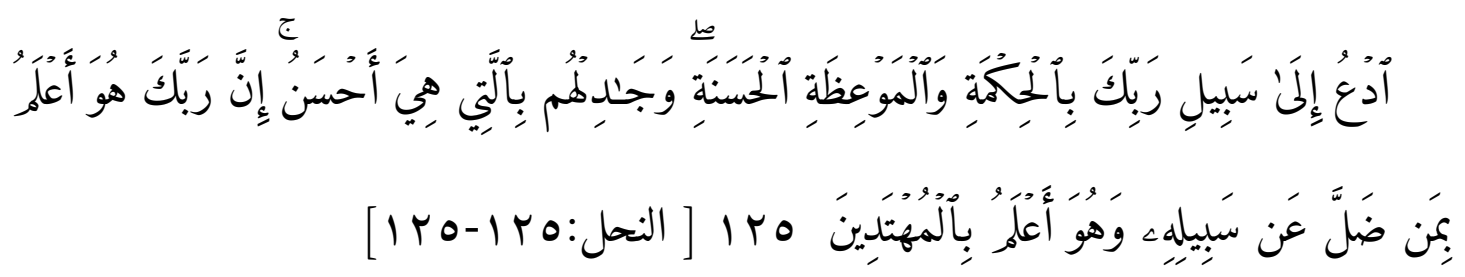

Serulah (manusia) kepada jalan Tuhan-mu dengan hikmah dan pelajaran yang baik dan bantahlah mereka dengan cara yang baik. Sesungguhnya Tuhanmu Dialah yang lebih 
mengetahui tentang siapa yang tersesat dari jalan-Nya dan Dialah yang lebih mengetahui orang-orang yang mendapat petunjuk. [An Nahl:125]

Sejarah perkembangan Islam di Indonesia mencatat bahwa pendakwah Islam telah menggunakan media dakwah sebagai alat transfer pesan kepada komunikannya. Misalnya adalah Sunan Kalijaga yang memiliki nama asli Raden Mas Said memanfaatkan wayang sebagai mediumnya (Marsaid, 2016). Wayang yang merupakan budaya Jawa yang diperkirakan telah ada di Nusantara pada abad ke-15 (Tim Penulis Sena Wangi, 1999). Dalam perjalanannya, wayang mengalami perkembangan yang sangat pesat dan mengalami transformasi dalam aspek visual dan aspek-aspek pendukung lainnya seperti; Karawitan, Sastra, dan lain sebagainya (Marsaid, 2016). Ternyata tak hanya wayang yang dijadikan oleh Sunan Kalijaga sebagai mediumnya, ada budaya lokal lain yang digunakan yaitu; Ukiran, Suluk, dan Gamelan (Kistanto, 2016).

Tidak hanya Sunan Kalijaga yang memanfaatkan media dakwah sebagai alat transfer pesan, namun Delapan Sunan yang lain juga telah menggunakan medium dalam berdakwah. Medium yang mereka gunakan sangat bervariasi guna menarik minat mereka para komunikan, seperti; mendirikan pesantren, berjualan kebutuhan pokok masyarakat dengan murah serta pengobatan gratis, mengajarkan bercocok tanam, dan lain sebagainya (Kistanto, 2016).

Seiring berjalannya waktu, dinamika perkembangan ilmu dan teknologi terus mengalami perubahan yang sangat signifikan dari masa ke masa. Hal ini membuat tatanan kehidupan masyarakat menjadi semakin kompleks dan maju. Kemajuan teknologi khususnya teknologi komunikasi dan informasi dijadikan peluang oleh para pendakwah untuk meluaskan dakwah mereka ke seluruh pelosok dunia. Cara yang ditempuh yaitu dengan menjadikan teknologi sebagai sarana atau media dalam berdakwah (Rakhmawati, 2016). Perilaku masyarakat yang cenderung mengikuti perkembangan teknologi menjadi tuntutan bagi para penyeru agama untuk terus melakukan inovasi dalam media dakwah agar pesan yang ingin disampaikan dapat diterima dengan baik oleh sasaran yang dituju.

Pada abad ke-21 masyarakat Islam telah memanfaatkan media massa yang canggih (sophisticated), sesuai karakteristik industrial-kapitalis (modernizedindustrialized capitalist-investor ), cenderung komersial (postindustrialized), dan sebagai alat (profit-taking) (Kistanto, 2016). Pada abad ini, siaran agama diselenggarakan secara massif dengan partisipan dari berbagai kelas dan strata yang ada. Dengan adanya siaran ini, partisipan dapat menikmati acara yang disajikan tanpa terhalang jarak, ruang, dan waktu. Acara tersebut disiarkan dengan berbagai bentuk siaran yang menarik dan beragam seperti; berita (news), hiburan, langsung (live), monolog, talk show, dan film. 
Tidak hanya media massa elektronik yang mengambil peran dalam menyebarkan dakwah Islam, namun media massa cetak juga berkontribusi dalam dunia dakwah (Kusumah, 2020). Misalnya, ditemukan majalah-majalah Islam yang khusus membahas permasalahan muslim dalam kehidupannya. Juga buletin atau kolom khusus dalam koran yang membahas agama Islam.

Saat ini, popularitas media massa elektronik maupun cetak mulai meredup. Kehadiran Media Sosial di tengah kehidupan masyarakat seakan memberi warna baru dan menjadi sebuah tren dalam kehidupan manusia. Fenomena ini pun, dijadikan oleh para aktivis dakwah sebagai kawan untuk melancarkan aktivitas dakwah mereka. Meskipun demikian, dunia dakwah masih tetap dan terus memanfaatkan kedua media massa elektronik dan cetak dalam menjalankan aktivitas dakwahnya.

Kini, media sosial yang sangat digandrungi oleh semua kalangan baik, baik muda maupun tua, telah menjadi kebutuhan primer tanpa mengenal ruang dan waktu. Inovasi yang terus dilakukan oleh mereka yang memiliki passion di bidang media sosial, menghasilkan ragam varian aplikasi yang menarik dan tidak membosankan. Varian aplikasi tersebut seperti; Facebook, Twitter, Path, Whatsapp, Instagram, Youtube, Telegram, Email, dan lain sebagainya (Suharto, 2017).

Berkembangnya varian aplikasi media sosial, meningkatkan pola minat konsumsi masyarakat terhadap aplikasi yang disuguhkan. Kini, masyarakat lebih menyukai suguhan video-video yang berdurasi pendek daripada video yang berdurasi panjang. Munculnya fenomena ini, memaksa mereka para aktivis dakwah mengubah style dakwah mereka. Mereka yang biasanya menyampaikan dakwah dalam durasi waktu yang cukup lama, mulai bergeser dengan membuat video-video yang berdurasi pendek.

Adanya transformasi media sosial dalam tatanan kehidupan manusia, membuat berbagai informasi dapat menembus ruang-ruang isolasi hingga ke pelosok nusantara (Suharto, 2017). Di tengah pandemi Covid 19 yang tengah melanda berbagai negara di belahan dunia, media sosial cukup diandalkan untuk dapat menjadi media pertama yang menyebarkan informasi secara massif tanpa ada batasan ruang dan waktu.

Ruang gerak masyarakat yang mulai dibatasi sejak kemunculan virus Covid 19, membuat masyarakat mencari jalan alternatif untuk melanjutkan hidupnya. Tidak hanya kebutuhan jasmani yang terpenuhi di masa sulit ini, namun kebutuhan rohani pun sangat diperlukan. Mengingat keadaan masyarakat yang retan terjangkit psikosomatis di masa pandemi ini (Novita, 2020), maka masyarakat muslim sangat membutuhkan suntikan vitamin rohani agar dapat merasakan 
ketenangan. Untuk itu, dibutuhkan optimalisasi dalam media dakwah selama berlangsungnya masa pandemi ini.

Berdasarkan uraian di atas, peneliti tertarik untuk membahas optimalisasi ragam media dakwah di tengah Pendemi Covid 19. Pembahasan ini diharapkan mampu membantu para aktivis dakwah untuk dapat mengoptimalkan dan melakukan pembaharuan dalam sarana dakwah yang mereka pilih dalam melebarkan dan menyebarkan dakwah mereka terutama di masa pandemi ini. Karena, tidak ada istilah deideologisasi Islam, karena Islam adalah agama yang paripurna yang harus terus disebarkan ajarannya.

\section{Metode Penelitian}

Penelitian ini menggunakan metode campuran (mixed methods) yaitu gabungan dari studi kepustakan dan literatur, serta menggunakan aplikasi analisis media sosial. Teknik pengambilan data diambil dengan cara mengkaji berbagai sumber literatur dari buku dan jurnal yang relevan dengan judul penelitian. Dengan menggunakan studi literatur, peneliti dapat belajar cara menulis karya tulis ilmiah yang lebih sistematis dan mengungakapkan buah pemikirannya dengan lebih kritis dan analitis dalam mengerjakan penelitiannya (Masyhuri \& Zainuddin, 2008). Setelah data terkumpul, peneliti melakukan analisis data dengan teknik analisis deskriptif dan interpretasi data. Adapun beberapa aplikasi analisis media social yang digunakan adalah Google Trends dan Telegram Analytics. Dengan teknik tersebut, peneliti berusaha menjelaskan materi kajiannya dengan hal-hal yang memiliki realitas dengan kehidupan manusia selama masa pandemi Covid 19 yang telah melumpuhkan aktivitas manusia.

\section{HASIL DAN PEMBaHASAN}

\section{Pengertian Media Dakwah}

Dalam bahasa latin, media adalah mediare yang artinya pengantara, alat penghubung atau alat yang digunakan. Selain itu, media juga sering disebut sebagai "Media is the extensions of man", yakni media adalah perluasan dari ide, gagasan dan pikiran terhadap kenyataan sosial. Marshall McLuhan mengungkapkan sebuah konsep yang berbunyi bahwa media adalah pesan itu sendiri (the medium is the message), dipahami bahwa media lebih dari sekedar wahana (Hamid dan Budianto, 2011). Dari beberapa pengertian di atas, maka media dakwah dapat diartikan sebagai wahana, sarana, kanal, alat, atau segala 
sesuatu yang dapat digunakan aktivis dakwah(komunikator) sebagai alat transfer pesan atau materi dakwah kepada komunikan.

Pengertian lain juga menyebutkan bahwa, secara etimologi, media juga berasal dari kata medius, yang artinya tengah, perantara, pengantar. Dalam bahasa Arab, media diartikan perantara atau pengantar pesan dari komunikator kepada komunikan. Media adalah segala sesuatu yang dapat dimanfaatkan untuk menyampaikan pesan dari pengirim kepada penerima, yang berfungsi memberikan rangsangan kepada pikiran, perasaan, perhatian dan minat (Rakhmawati, 2016). Sedangkan pengertian media dakwah menurut Al Bayanuni adalah

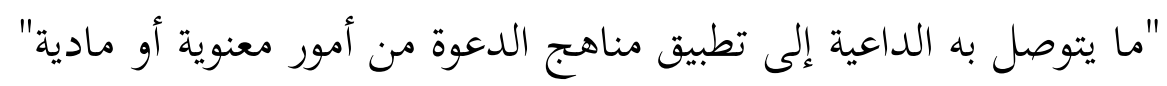

"Alat yang dijadikan daiyah sebagai perantara untuk menerapkan konsep-konsep dakwah baik secara moral maupun material".

Dari beberapa pengertian di atas, maka peneliti berusaha menyimpulkan bahwa media dakwah dapat diartikan sebagai wahana, sarana, kanal, alat, atau segala sesuatu yang dapat digunakan aktivis dakwah(komunikator) sebagai alat transfer pesan atau materi dakwah kepada komunikan.

\section{Ragam Media Dakwah}

Media dakwah atau dalam bahasa Arab disebut sebagai wassail ad-dakwah terbagi menjadi enam buah alat (Sanwar, 1986), yaitu;

1. Dakwah melalui saluran lisan, yaitu dakwah yang dilakukan secara langsung oleh dai(komunikator) kepada komunikan. Alat yang digunakan yaitu, televisi, radio, live steaming on YouTube maupun Instagram.

2. Dakwah melalui saluran tertulis, yaitu dakwah yang dilakukan dengan menggunakan tulisan-tulisan. Kegiatan dakwah ini dapat dilakukan melalui surat kabar, majalah, selebaran, spanduk, buletin, brosur, buku, dan lain sebagainya.

3. Dakwah melalui saluran visual, yaitu kegiatan dakwah yang dilakukan dengan alat yang dapat dilihat oleh mata manusia dan memiliki nilai estetika. Alat yang dapat digunakan yaitu; kaligrafi, seni ukir, seni tulis, dan lain sebagainya.

4. Dakwah melalui saluran audio, yaitu dakwah yang dilakukan dengan menggunakn perantara indra pendengaran. Media atau alat yang dapat digunakan yaitu, tape recorder, kaset, rekaman, dan lain-lain. 
5. Dakwah melalui saluran audio visual, yaitu dakwah yang menggabungkan dua saluran dakwah, yaitu saluran audio dan saluran visual. Dengan saluran ini, sasaran dakwah dapat menikmati materi dakwah yang disampaikan. Alat yang digunakan dalam saluran ini seperti; video, TV, wayang kulit, seni drama, dan lain-lain.

6. Dakwah melalui keteladanan. Penyampaian dakwah dengan media media ini melalui penampakan konsekuensi da'I antara pernyataan dan pelaksanaan. Dengan media ini, para komunikan dapat meniru perilaku yang dicerminkan oleh komunikator (da`i).

Enam macam media dakwah menurut Sanwar

\begin{tabular}{lll}
\hline No & \multicolumn{1}{c}{ Ragam Media Dakwah } & \multicolumn{1}{c}{ Aplikasi Media Dakwah } \\
\hline 1 & Dakwah melalui saluran lisan & TV, radio, live steaming, Instagram \\
2 & Dakwah melalui saluran tertulis & Surat kabar, majalah, selebaran, buku \\
3 & Dakwah melalui saluran visual & Kaligrafi, seni ukir, seni tulis \\
4 & Dakwah melalui saluran audio & Tape recorder, kaset, rekaman \\
5 & Dakwah melalui saluran audio visual & Video, TV, wayang kulit, seni drama \\
6 & Dakwah melalui keteladanan & Perilaku dan sikap dalam kehidupan nyata \\
\hline
\end{tabular}

Terdapat pembagian lain yang menjelaskan bahwa beberapa media yang dapat dimanfaatkan agar mendapatkan hasil yang maksimal (Rakhmawati,2016), yaitu;

Pertama, Media Tatap Muka Sebagai Media Komunikasi. Media tatap muka merupakan media yang dipecaya sangat efektif dalam menyampaikan pesan. Hal ini terjadi karena adanya respon langsung yang diterima oleh para aktivis dakwah dari sasaran dakwah mereka terhadap pesan yang telah mereka sampaikan. Media ini, juga terkesan sangat murah, praktis, dan strategis. Murah karena dakwah ini tidak membutuhkan anggaran dana yang tinggi. Mereka hanya cukup datang dan mendengarkan pemaparan materi. Jika ada sesuatu yang belum dipahami atau ingin disampaikan para pendengar (komunikan) dapat bertanya dan menyampaikan secara langsung untuk memperoleh penjelasan secara jelas. Dengan penjelasan ini, terwujudlah kesepahaman antara kedua belah pihak, yaitu pihak komunikator dan pihak komunikan. Praktis, karena tidak ada basa-basi dalam media ini. Kehadiran mereka seakan menjadi ajang silaturahmi antar 
sesama muslim. Sehingga mereka dapat merasakan keadaan mereka satu sama lain, saling menghargai, dan bersyukur atas segala perbedaan. Strategis karena dapat menumbuhkan gairah dan pertemanan antar sesama muslim yang luar biasa. Baik itu, kelegaan ketika dapat mengobati rasa rindu maupun kepuasan ketika memiliki teman baru.

Kedua, Media Audio Visual. Media berupa; teater, film, dan televisi. Kelebihan media ini dapat menyampaikan pesan hingga ke rumah-rumah dan dapat dinikmati di mana saja. Tidak hanya itu, media ini dapat meyampaikan ide dengan mengguankan metode yang modern. Eksistensi media ini dirasa sangat istimewa dan diperhitungkan, karena sajiannya yang sangat dinanti menjadi salah satu pembentuk opini publik. Ditambah lagi perilaku hidup masyarakat yang terkesan mengikuti perkembangan dunia dan terus menginginkan informasi yang actual membuat masyarakat menaruh harapan pada media ini untuk dapat terus memberikan inovasi yang menarik. Dakwah melalui media film dan televisi, dapat dibentuk untuk menyajikan informasi yang islami. Misalnya, penulisan artikelartikel tentang keislaman, maupun kisah-kisah sejarah islam yang dikemas dengan menggunakan gaya bahasa yang sangat indah melalui media audio visual sangat menarik untuk dikaji (Aziz, 2004).

Ketiga, Media Visual. Media visual yang dapat dijadikan sebagai perantara dalam menyamapaikan pesan, yaitu; peta dan foto-foto kejadian. Kejadiankejadian tersebut seperti; peristiwa bencana alam, puing-puing kehancuran akibat perang serta kezaliman yang terjadi di tengah umat. Seperti sejarah berdirinya kerajaan Samudra Pasai, kerajaan Mataram, kerajaan Demak yang kesemuanya tidak dapat terlepas dari beberapa cerita dakwah yang dapat dikomunikasikan dengan menggunakan media visual yang memudahkan generasi muda untuk belajar dan memahami kejadian yang terjadi di masa lampau, yang dapat dijadikan sebagai cerminan dan tolak ukur dalam menentukan sikap di masa mendatang.

Keempat, Media Individual. Media ini dapat berupa siaran radio, kaset-kaset khutbah atau pelajaran. Di masa yang sedang dan terus mengalami kemajuan ini, media tersebut dapat ditemukan dengan mudah karena telah menjadi produk pasar yang dijual diberbagai tempat. Masing-masing media memiliki berbagai karateristik yang menjadi pembeda dan menjadi sebuah ciri khas media tersebut. Kelebihannya menjadi sebuah nilai plus, sedangkan kekurangannya menjadi sebuah tantangan untuk terus melakukan inovasi. Misalnya; siaran radio. Radio yang awalnya hanya dapat menyajikan siaran local dan dibatasi oleh ruang, kini siaran radio dapat dinikmati oleh semua orang dengan skala besar tanpa ada pembatas yang bernama ruang. Tidak hanya itu, dengan radio kita juga dapat 
menikmati siaran streaming yang disiarkan secara serentak di berbagai negara di belahan dunia.

Kelima, Media dakwah melalui lisan. Sebagai media dalam berdakwah, media pembinaan umat, dan mauidzah hasanah, maka materi khutbah harus dipersiapkan dengan baik. Bila dicermati, khutbah jumat menjadi salah satu wadah pembinaan yang bersifat indroktiner, yang mewajibkan para jamaah untuk menyimak dengan tekun, dan menuntut pendengarnya untuk diam dan mendengarkan, karena kedua hal tersebut, wajib hukumnya (Hafiduddin, 1998). Khutbah jumat, yang dilaksanakan rutin satu kali dalam seminggu, memberikan ruang bagi juru dakwah untuk memberikan tema yang beragam agar pengetahun kaum muslim tentang agama semakin luas.

Keenam, Media elektonik. Hamzah Yaqub membagi media yang digunakan sebagai sarana dakwah menjadi media tradisional dan modern. Tidak mengherankan apabila jumlah media dakwah sangatlah banyak. Contoh media tersebut dari yang tradisional sampai modern yaitu; bedug, pagelaran, kentongan, wayang, kesenian, surat kabr, papan pengumuman, film, radio, televisi, dan lain sebagainya. Untuk dapat menarik minat sasaran dakwah dan respon baik dari mereka, dapat dilakukan penggabungan dari beberapa media dakwah tersebut dengan memperhatikan tujuan yang akan dicapai, pesan yang ingin disampaikan, serta teknik yang digunakan.

Enam macam media dakwah menurut Rahmawati

\begin{tabular}{|c|c|c|c|}
\hline No & Ragam Media Dakwah & Keunggulan & Kekurangan \\
\hline 1 & Media Tatap Muka & $\begin{array}{lll}\begin{array}{l}\text { murah, } \\
\text { strategis }\end{array} & \text { praktis, } & \text { dan }\end{array}$ & $\begin{array}{l}\text { Bila berjauhan tidak bisa } \\
\text { terlaksana }\end{array}$ \\
\hline 2 & Media Audio Visual & $\begin{array}{l}\text { Dapat menyampaikan pesan } \\
\text { dalam cangkupan wilayah } \\
\text { yang luas dan dalam waktu } \\
\text { yang sama }\end{array}$ & $\begin{array}{l}\text { Tidak dapat dinikmati di } \\
\text { setiap tempat }\end{array}$ \\
\hline 3 & Media Visual & $\begin{array}{l}\text { Adanya gambaran tentang } \\
\text { suatu peristiwa yang terjadi } \\
\text { di masa lampau }\end{array}$ & $\begin{array}{l}\text { Tidak semua individu dapat } \\
\text { memahami pesan yang akan } \\
\text { disampaikan }\end{array}$ \\
\hline 4 & Media Individual & $\begin{array}{l}\text { Dapat diputar dinikmati } \\
\text { kapan saja }\end{array}$ & $\begin{array}{l}\text { Tegeser oleh perkembangan } \\
\text { teknologi }\end{array}$ \\
\hline 5 & Media melalui lisan & $\begin{array}{l}\text { Dapat menerapkan metode } \\
\text { mauidzhah hasanah }\end{array}$ & $\begin{array}{l}\text { Munculnya rasa bosan karena } \\
\text { penyajiannya yang monoton }\end{array}$ \\
\hline 6 & Media elektonik & $\begin{array}{l}\text { Efektif, } \\
\text { menyampaikan } \\
\text { secara massif }\end{array}$ & Bergantung pada sinyal \\
\hline
\end{tabular}


Saat ini, media elektronik juga aktif dalam berkontribusi dalam mewujudkan perkembangan media yang dimanfaatkan sebagai sarana dakwah, diantaranya adalah sebagai penunjang dakwah :

Pertama, Media Internet. Internet yang berasal dari kata interconnection networking yang berarti jaringan internasional. Jaringan tersebut terbentuk dari banyaknya jaringan kecil atau LAN (Local Area Network) yang saling tergabung menjadi satu jaringan computer internasional atau WAN (Wide Area Network) (Tim Penyusun, 2010: 4). Dengan jaringan ini, pemakai computer dapat terhubung dengan pemakai computer lainnya yang berada di tempat yang berbeda-beda dengan cangkupan wilayah yang berskala besar. Sehingga apabila media ini dimanfaatkan untuk berdakwah, dakwah dapat memainkan perannya untuk terus menyebarkan Islam ke seluruh penjuru tanpa mengenal tempat dan waktu dandapat diakses oleh semua etnik dari berbagai golongan (Ali Aziz, 2009).

Terdapat tiga keunggulan media internet dibanding media yang lainnya, yaitu; (1) media ini bersifat never turn-off yaitu tidak pernah dimatikan dan unlimited access yaitu dapat diakses tanpa batas, (2) tempat yang sesuai untuk menceritakan pengalaman spiritual yang sifatnya tidak rasional sehingga kurang pantas bila dibawa ke forum umum, (3) memberikan kemudahan bagi mereka yang mengalami kesulitan dalam berkomunikasi untuk terus mendapatkan kepuasan spiritual. Kelebihan-kelebihan ini, seharusnya dapat dimanfaatkan dengan sebaik-baiknya karena sangat efektif merealisasikan tujuan dakwahnya (Rohandi dan Taufik, 2003).

Setidaknya ada tiga metode dakwah yang dapat dapat dilakukan dengan menggunakan internet (Ma`arif, 2010) yaitu;

1. Menggunakan fasilitas website. Berdakwah menggunakan fasilitas ini telah dilakukan oleh banyak tokoh-tokoh ulama dan organisasi Islam, karena dianggap lebih fleksibel dan luas. Misalnya; ukhuwah.or.id, Indohalal.com, myquran.com, dan lain sebagainya.

2. Menggunakan fasilitas mailing list. Caranya dengan melakukan diskusi maupun dengan mengirimi pesan. Misalnya; TafsirQuran@yahoo.group.com, Pesantrengroup@yahoo.com, dan sebagainya.

3. Menggunakan fasilitas chatting. Kelebihan yang dimiliki oleh fasilitas ini, memungkinkan interaksi secara langsung, Namun ruang lingkupnya sempit.

Sedangkan menurut Ahmad Zaini dalam tulisannya yang berjudul Dakwah Melalui Internet, menyebutkan metode dakwah lain yang dapat dilakukan dengan menggunakan internet yaitu; (a), menggunakan fasilitas blog. Fasilitas ini 
memiliki kesamaan dengan fasilitas website. Pemilik blog dapat memberikan atau mengisi blog-nya denhan informasi seputar urusan keagamaan. (b), menggunakan fasilitas jejaring social, seperti; facebook, you tube, twitter, dan lain sebagainya (Tim Penyusun, 2010).

Kedua, media televisi. Di era ini, televisi telah menjadi kebutuhan primer manusia. Setiap program acaranya telah berhasil menyedot perhatian dari berbagai kalangan. Bahkan tayangan yang ditampilkan telah berhasil membentuk opini public secara serentak. Kini penyiran televisi, dihebohkan dengan munculnya polemic perubahan siaran televisi digital (high definition television) dan siaran televisi analog (standard definition television). Keberadaan kedua jenis televisi ini, telah membantu dalam mempermudah dakwah Islam (Tamburaka, 2013).

Ketiga, media radio. Penggunaan radio sebagai kanal penyampaian pesan dapat diartikan sebagai penyampaian informasi kepada khalayak ramai berupa suara yang berjalan satu arah yang memanfaatkan gelombang radio sebagai medianya. Radio juga tehitung sebagai media yang murah, dan fleksibel, karena penikmat radio tidak perlu menyiapkan anggaran yang besar ketika ingin menikmati siarannya. Meskipun demikian, radio memiliki potensi tekena gangguan dalam frekuensi yang lumayan banyak.

Keempat, media cetak. Media cetak merupakan media yang menyampaikan berita secara periodik. Beberapa ciri media cetak adalah : Pertama, terekam. Artinya berita yang dimuat tersusun secara sistematis. Kedua, pesan yang disampaikan menyangkut kebutuhan khalayak. Ketiga, memberikan efek yang sesuai dengan tujuan yang ingin dituju. Contoh dari media cetak lainnya selain surat kabar adalah buku, majalah.

Kontribusi media internet dalam dakwah

\begin{tabular}{lll}
\hline No & Media Sosial & \multicolumn{1}{c}{ Bentuk Kontribusi } \\
\hline 1 & You Tube & $\begin{array}{l}\text { Menghadirkan konten-konten menarik tentang pengetahun, nasihat, motivasi, } \\
\text { yang sesuai dengan syariat Islam. Aplikasi ini telah berhasil mencuri perhatian } \\
\text { public, dan dijadikan sebuah lading untuk menyampaikan dakwah. }\end{array}$ \\
& & $\begin{array}{l}\text { Memberikan sebuah forum untuk berdiskusi tentang hal-hal yang wajib } \\
\text { diketahui seorang muslim, yaitu dengan memanfaatkan media chat grup }\end{array}$ \\
\hline
\end{tabular}

Pada hakikatnya, media atau perantara dakwah sangatlah beragam. Tergantung situasi dan kondisi yang dialami oleh para da`i (komunikator) dan mad`u (komunikan). Agar dapat terus eksis dalam dunia dakwah dan pesannya dapat diterima dengan baik, sudah selayaknya para aktivis dakwah teru melakukan inovasi dalam berdakwah sesuai dengan perkembangan teknologi 
yang sangat menunjang. Sehingga tidak akan muncul kesan monoton yang membuat pendengarnya merasa bosan karena mendapat sajian yang sama tiap pertemuannya.

\section{Optimalisasi Media Dakwah di Tengah Pandemi}

Virus 2019-nCoV atau Covid-19 (istilah terbaru) telah menjadi isu kesehatan global. Virus yang berasal dari Wuhan, China tersebut, telah mewabah mulai awal Januari 2020. Sudah banyak korban yang berjatuhan karena terpapar virus ini. Untuk itu, pemerintah mengambil langkah awal yaitu berupa anjuran social distancing, yang diharapkan mampu menekan jumlah pertumbuhan dan penyebaran virus ini (Yunus, 2020). Tidak hanya itu, pemerintah juga menghimbau masyarakat untuk terus berada di rumah dan tidak keluar kecuali karena hal yang sangat mendesak. Maka tidak aneh lagi, jika mendengar jargonjargon yang berbunyi; stay at home, work from home, dan lain sebagainya. Keadaan ini pun, menjadikan segala bentuk aktivitas masyarakat dari berbagai sektor mengalami kelumpuhan.

Dalam agama Islam, dakwah harus terus berjalan bagaimana pun keadaanya. Karena agama merupakan kebutuhan spiritual yang harus terpenuhi kebutuhannya. Bila kebutuhan ini tidak terpenuhi, akibatnya manusia akan dengan mudah terkena penyakit psikosomatis (Novita, 2020). Untuk itu, dakwah harus terus berjalan apapun keadaanya, agar tidak terjadi deideologisasi Islam. Cara terbaik yang dapat ditempuh adalah dengan memanfaatkan media dakwah yang memiliki peluang besar untuk dapat diterima masyarakat di tengah pandemi yang sedang berlangsung.

Media dakwah yang paling tepat dan aman untuk dijadikan sebagai perantara di tengah wabah Corona yang memaksa setiap manusia untuk terus melakukan social distancing dan phisycal distancing adalah sebagai berikut;

a. Televisi. Keberadaan televisi di rumah setiap individu bukan menjadi hal asing lagi. Pasalnya televisi sangat digandrungi oleh semua kalangan. Terutama di saat pandemi ini, orang-orang menghabiskan hampir seluruh waktunya di rumah tentunya sambal menikmati siaran televisi. Untuk itu, siaran ceramah keagamaan yang frekuensinya sangat sedikit dalam setiap harinya, harus ditambah lagi porsinya. Tidak hanya penambahan porsi, melainkan penambahan kemasan dalam setiap siarannya. Agar pemirsa Tv tidak bosan dan tertarik untuk mendengarkan pesan yang akan di sampaikan. 
b. Media social. Media social menyajikan berbagai fasilitas yang selalu menarik perhatian masyarakat dalam jumlah banyak. Kemudahan dalam mengakses dan memanfaatkan media ini menjadikan masyarakat betah untuk terus berlama-lama dalam social media. Jika fasilitas dalam media ini dapat kita manfaatkan dengan sebaik-baiknya untuk menyampaikan dakwah yaitu dengan mengahadirkan konten-konten yang menarik perhatian namun tetap berisi pengetahuan tentang keagamaan tentunya para netizen dapat beralih untuk selalu mendengarkan dan menyaksikan pesan yang disampaikan. Di antara Media Sosial yang banyak diakses adalah Youtube (Rahma, Farida Nur, \& Kusumah, Mada Wijaya, 2020).

c. Media cetak. Meskipun keberadaan media ini mulai tergeserkan, namun ternyata media ini masih diminati oleh kalangan tertentu. Untuk itu, media ini harus terus mendapatkan sentuhan-sentuhan inovasi yang memberikan ruang lebih kepada Islam, untuk menginformasi keparipurnaan media ini.

d. Radio. Media ini juga masih sangat diminati oleh masyarakat. Siaran yang sifatnya local kini telah menjadi lebih luas, dan dapat dapat dinikmati secara serentak dalam cangkupan wilayah yang luas.

Empat macam media dakwah di tengah wabah Corona

\begin{tabular}{llcl}
\hline No & $\begin{array}{c}\text { Ragam Media } \\
\text { Dakwah }\end{array}$ & $\begin{array}{c}\text { Apakah Efektif } \\
\text { dan Aman }\end{array}$ & Keterangan \\
\hline 1 & Televisi & $\checkmark$ & $\begin{array}{l}\text { Digemari masyarakat dan tidak ada kontak fisik } \\
\text { langsung antara komunikan dan komunikator } \\
\text { Terdapat varian aplikasi yang menyuguhkan } \\
\text { berbagai siaran, praktis, strategis }\end{array}$ \\
3 & Media Sosial & $\checkmark$ & Tidak ada kontak fisik secara langsung \\
4 & Radio & $\checkmark$ & Siaran dapat dinikmati tanpa adanya kontak fisik \\
\hline
\end{tabular}

Grafik berikut ini menunjukkan angka pengguna Media Sosial (khususnya: Telegram salah satu Organisasi Islam) sebelum adanya wabah Corona. Pada tanggal 08 Oktober 2019 subscribers berjumlah 7.177 orang kemudian pada 30 Desember 2019 berjumlah 7.460 orang. 
Sofiyanti dan Kusumah

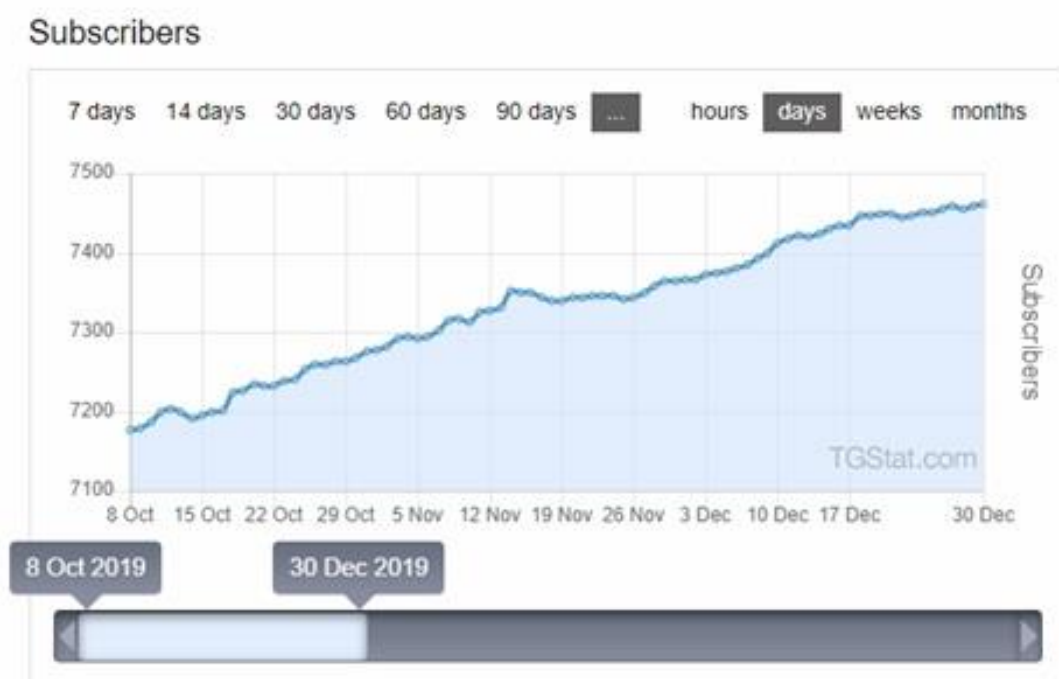

Grafik berikut ini menunjukkan adanya peningkatan angka pengguna Media Sosial (khususnya: Telegram salah satu Organisasi Islam) di masa pandemi Corona 19. Pada tanggal 31 Desember 2019 subscribers berjumlah 7.177 orang kemudian pada 3 Juli 2020 berjumlah 8.948 orang.

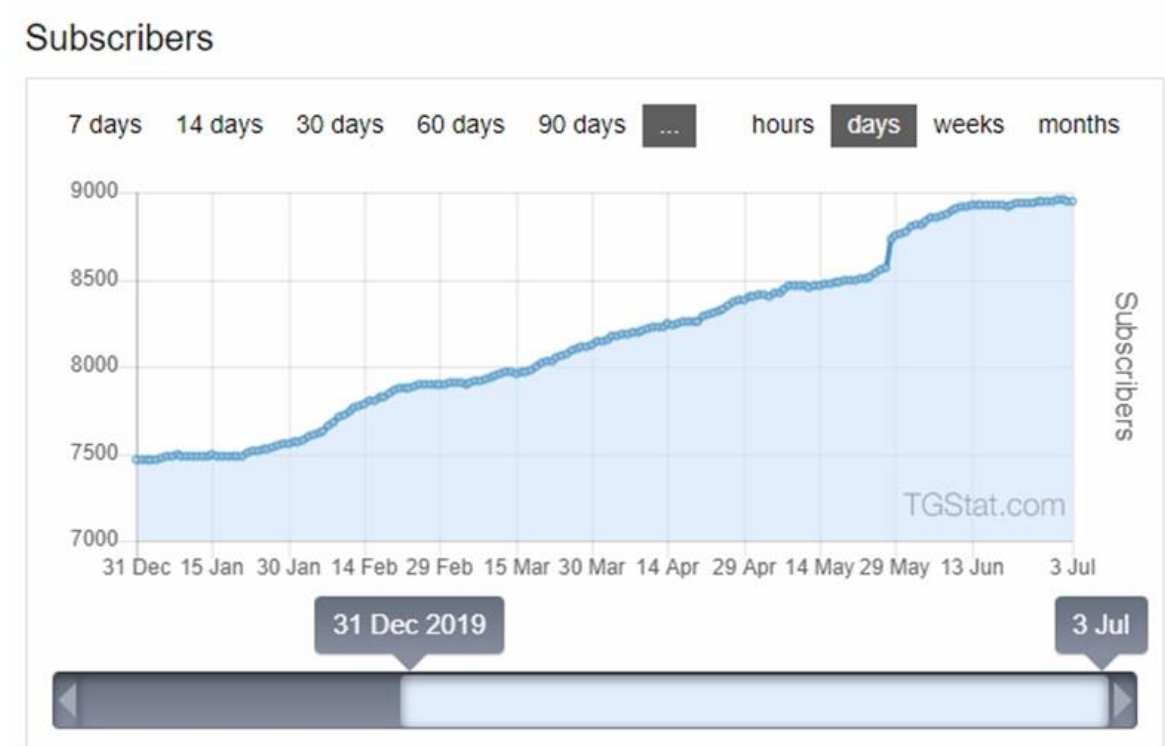

Grafik berikut ini menunjukkan angka pengguna Media Sosial (khususnya: Telegram salah satu Dai Nasional) sebelum adanya wabah Corona. Pada tanggal 17 Januari 2019 subscribers berjumlah 15.402 orang kemudian pada 30 Desember 2019 berjumlah 16.951 orang. 


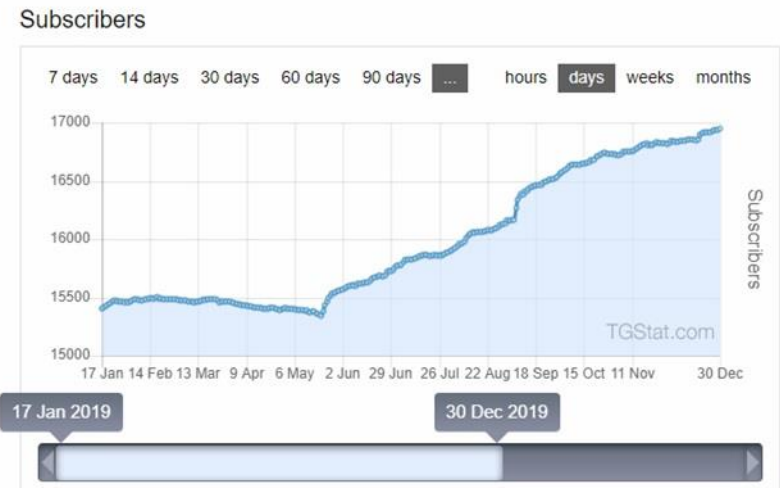

Recent posts

2. Fellix Siauv

Beyond The Inspiration 32: Rahasia Anti-Galau \& Anti-Sedih

Pesan Allah pada hamba-hamba-Nya sudah jelas. Dia adalah pencipta manusia, Dia Mahatahu terhadap hamba-hamba-Nya. termasuk apapun yang terbaik bagi mereka di dunia dan kehidupan mereka

Allah berpesan sebelum mengutus manusia ke dunia untuk bertugas menjadi penjaga bumi. "Nanti Aku turunkan pada kalian petunjuk, siapa mengambilnya, tak ada khawatir pada mereka, tak pula sedih", begitu

READ MORE

Grafik berikut ini menunjukkan adanya peningkatan angka pengguna Media Sosial (khususnya: Telegram salah satu Dai Nasional) di masa pandemi Corona 19. Pada tanggal 31 Desember 2019 subscribers berjumlah 16.951 orang kemudian pada 4 Juli 2020 berjumlah 20.100 orang.

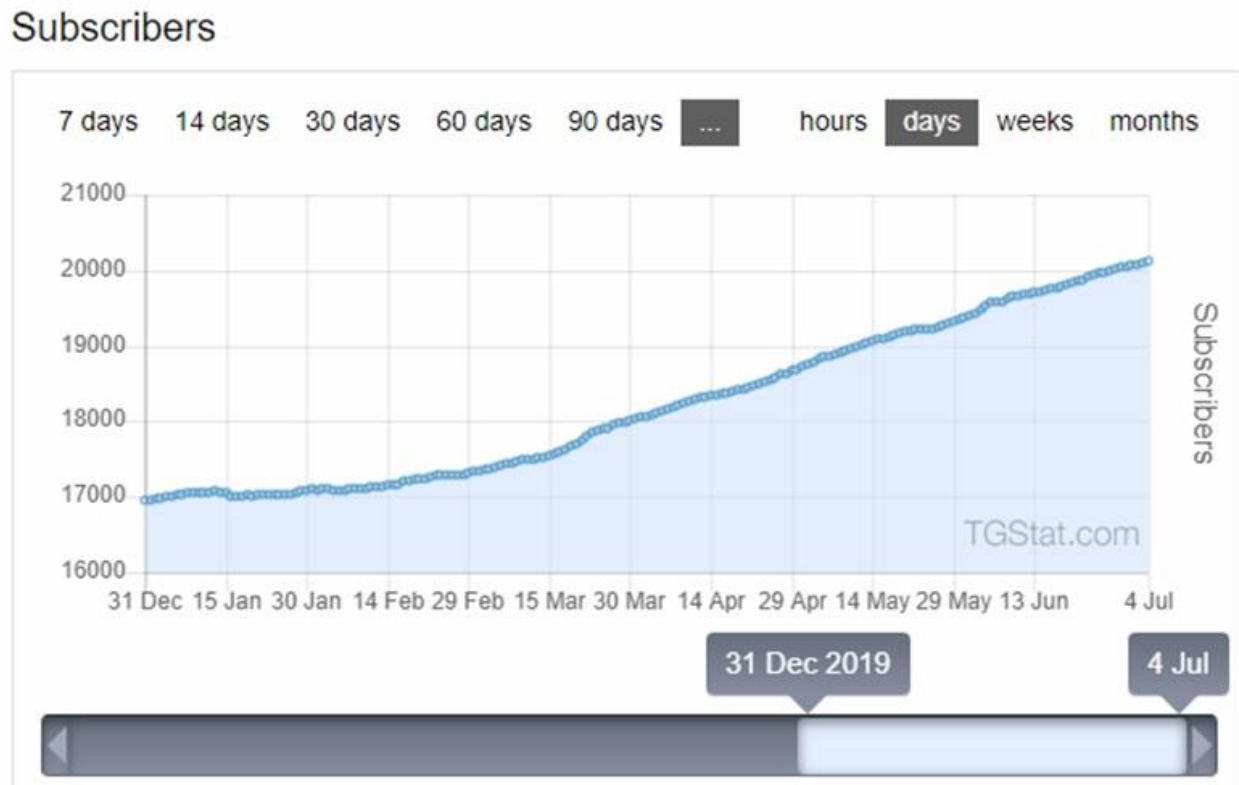

Dari grafik tersebut menunjukan masyarakat Indonesia saat Pandemi Covid 19 memilih penggunaan media sosial dalam mengikuti kajian Islam. Berikut ini grafik yang menunjukan penggunaan media social seiring berjalannya waktu, yaitu; 


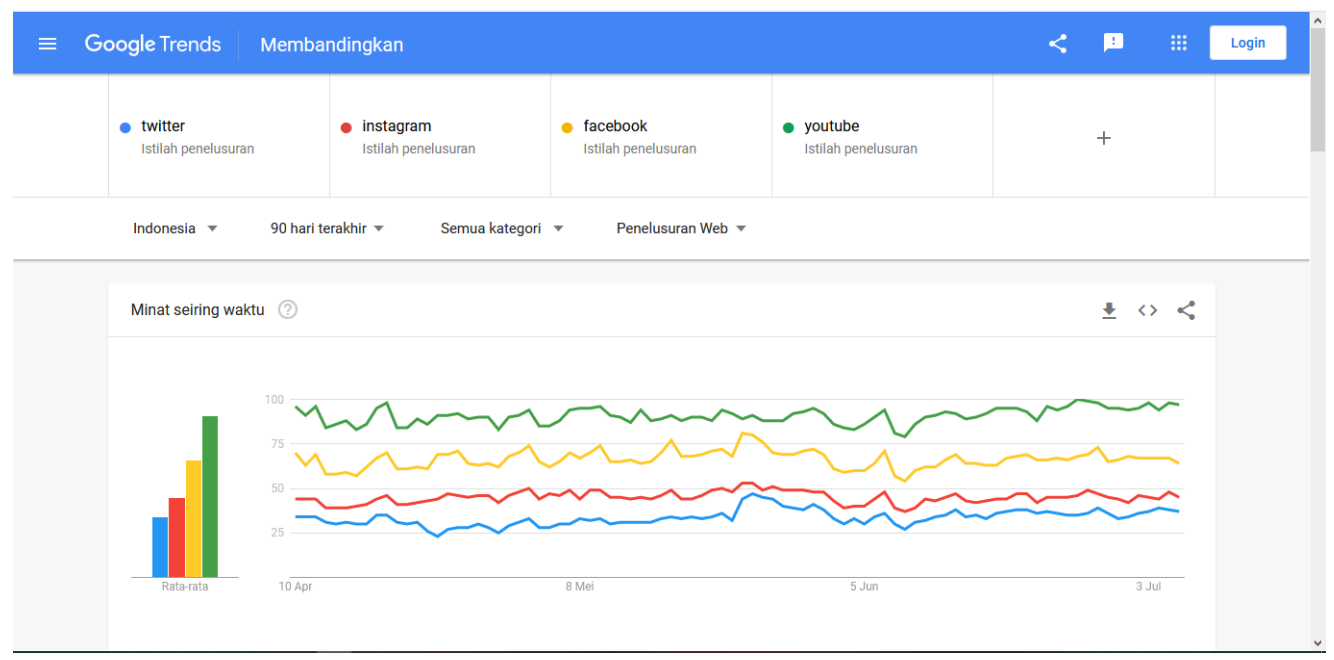

\section{KesimpUlAn}

Dari berbagai pemaparan dan penjelasan diatas peneliti berusaha menyimpulkan gagasan tersebut menjadi beberapa hal, yaitu; media dakwah dapat diartikan sebagai wahana, sarana, kanal, alat, atau segala sesuatu yang dapat digunakan aktivis dakwah (komunikator) sebagai alat transfer pesan atau materi dakwah kepada komunikan.

Media dakwah juga menjadi penunjang tercapainya tujuan dan tersampaikannya pesan kepada sasaran dakwah yang dituju. Hal ini terjadi karena dakwah merupakan salah satu unsur dalam berdakwah. Apabila salah satu unsur tidak ada atau tidak optimal, maka segala rencana yang diharapkan keberhasilannya akan sukar direalisasikan. Untuk itu, media dakwah harus selalu optimal.

Perkembangan teknologi dari masa ke masa mengalami kemajuan yang sangat signifikan. Hal ini menjadikan media dakwah memiliki jumlah yang sangat banyak. Hingga tejadi pembagian media menjadi media dakwah tradisional dan modern. Contohnya; bedug, pagelaran, kentongan, wayang, kesenian, surat kabr, papan pengumuman, film, radio, televisi, dan lain sebagainya.

Pada hakikatnya, media atau perantara dakwah sangatlah beragam. Tergantung situasi dan kondisi yang dialami oleh para da`i (komunikator) dan mad`u (komunikan). Agar dapat terus eksis dalam dunia dakwah dan pesannya dapat diterima dengan baik, sudah selayaknya para aktivis dakwah teru melakukan inovasi dalam berdakwah sesuai dengan perkembangan teknologi yang sangat menunjang. Sehingga tidak akan muncul kesan monoton yang membuat pendengarnya merasa bosan karena mendapat sajian yang sama tiap pertemuannya. 
Di tengah polemik kehidupan yang kian memanas yaitu dengan adanya Virus 2019-nCoV atau Covid-19 (istilah terbaru) yang berasal dari Wuhan, China tersebut, menjadikan masyarakat seakan tenggelam dan terpuruk dengan keadaan yang disebabkan oleh virus tersebut. Maka tidak aneh jika sebagian masyarakat terkena psikosomatis, yang dipicu rasa cemas dan tidak tenang berlebih karena merasa tertekan oleh keadaan yang jauh dari ketenangan.

Langkah pencegahan yang dapat dilakukan yaitu dengan memenuhi kebutuhan spiritual yang akan memberikan ketenangan pada setiap diri. Untuk itu, dakwah harus terus berjalan bagaimana pun keadaannya. Alasan utamanya yaitu agar tidak terjadi deideologisasi Islam. Cara terbaik yang dapat ditempuh adalah dengan memanfaatkan media dakwah yang memiliki peluang besar untuk dapat diterima masyarakat di tengah pandemi yang sedang berlangsung.

Media dakwah yang paling tepat dan aman untuk dijadikan sebagai perantara di tengah wabah Corona yang memaksa setiap manusia untuk terus melakukan social distancing dan phisycal distancing adalah sebagai berikut, yaitu; televisi, media social, media cetak, dan radio. Pemanfaatan berbagai media ini yaitu dengan menambah frekuensi siaran, mengusung tema-tema yang menarik, memberikan kemasan baru dalam penyajiannya, serta terus melakukan inovasiinovasi agar dakwah dapat berkembang sehingga Islam dapat sampai hingga ke pelosok-pelosok negeri.

\section{DAFTAR PUSTAKA}

Al Bayanuni, Muhammad Al Fath. 1995. Al Madkhal Ila Ilmi Ad Dakwah. Beirut: Muassasah Ar Risalah.

Aziz, Moh. Ali. 2009. Ilmu Dakwah. Jakarta: Kencana.

Al Qur`an Word.

Fakhruroji, Moch. 2010. “ Dakwah Islam dan Inovasi Media : Peluang Media Global atas Dakwah Islam”. Komunika. Vol. 4, No. 1.

Farid Hamid dan Heri Budianto (ed). 1999. Ilmu Komunikasi sekarang dan Tantangan Masa Depan, Jakarta: Kencana Prenada Media Group.

Gunawan, I. 2013. Metode Penelitian Kualitatif: Teori dan Praktik. Jakarta: Bumi Aksara.

Hafidduddin, Didin. 1998. Dakwah Aktual. Jakarta : Gema Insani.

https://tgstat.com/channel/@felixsiauw dikunjungi pada jumat 10 juli 2020 pukul 07.30 WIB. 
https://tgstat.com/channel/@DewanFatwaPA . Dikunjungi Dikunjungi pada hari Jumat, 10 juli 2020 pukul 09.15 WIB.

https://trends.google.com/trends/explore?date=today\%203m\&geo=ID\&q=twitter,instagram,facebook,youtube. Dikunjungi pada hari Jumat, 10 juli 2020 pukul 08.50 WIB.

Kistanto, Nuerdin Harry. (tt). "Agama dan Media Massa Tradisional dan Industrial". Endogami.

Kusumah, Mada Wijaya. (2020). Konvergensi Media Dakwah Di Masa Pandemi Covid 19. Zenodo. http://doi.org/10.5281/zenodo.4018177

Marsaid. 2016. “Islam dan Kebudayaan : Wayang sebagai Media Pendidikan Islam di Nusantara". Kontemplasi. Vol. 4, No. 1.

Masyhuri, \& Zainuddin. 2008. Metodologi Penelitian - Pendekatan Praktis dan Aplikatif. Bandung: Refika Aditama.

Moh. Ali Aziz. 2009. Ilmu Dakwah. Jakarta: Kencana Prenada Media Group.

Novita, Tarisa. 2020. "Covid dan kecenderungan Psikosomatis".

Rakhmawati, Istina. 2016. "Perkembangan Media Sebagai Sarana Dakwah". At Tabsyir. Vol. 4, No. 1.

Rohandi, Abdul fatah dan Taufik, M. Tata. 2003. Manajememen Dakwah diera global sebuah pendekatan metodologi. Jakarta: Amissco.

Sanwar, M. Aminuddin. 1986. Pengantar Ilmu Dakwah, Semarang: Fakultas Dakwah IAIN Walisongo.

Suharto. 2o17. "Media Sosial Sebagai Medium Komunikasi Dakwah". Al Misbah. Vol. 13, No. 2.

Rahma, Farida Nur, \& Kusumah, Mada Wijaya. (2020). Youtube sebagai Media Dakwah Masa Pandemi Covid 19 (Studi Analisis Konten Dakwah Channel Muslimah Media Center 15-30 Juni 2020). Zenodo. http://doi.org/10.5281/zenodo.4018170

Tamburaka, Apriadi. 2013. Literasi Media. Jakarta: Raja Grafindo Persada.

Tim penulis Sena Wangi. 1999. Ensiklopedi Wayang Indonesia, jilid VI. Jakarta: Seni Wangi.

Tim Penyusum. 2010. Menggenggam Dunia dengan Internet. Yogyakarta: Andi Offset dan Madcoms.

Ya'qub, Hamzah. 1992. Publistik Islam: Teknik Dakwah dan Leadership. Bandung: CV. Diponegoro. 
Yunus, Nur Rohim. 2020. "Kebijakan Pemberlakuan Lockdown Sebagai Antisipasi Penyebaran Corona Virus Covid 19”. Salam. Vol.7, No. 3. 